\title{
Animal performance on Tanzânia grass pasture intercropped with Estilozantes Campo Grande or fertilized with nitrogen
}

\author{
ULYSSES CECATO, BRUNO S. IWAMOTO, EDMAR P. PELUSO, GRACIELLE C. MARI, \\ VINICIUS V. PEREIRA AND JOSÉ M. SAUTE
}

Universidade Estadual de Maringá, Maringá, PR, Brazil. www.ppz.uem.br

Keywords: Nitrogen fertilization, grass-legume pasture, pasture quality, Panicum maximum, Stylosanthes.

\section{Introduction}

Nitrogen $(\mathrm{N})$ is the most important nutrient for growth and development of pastures, giving the plant a faster growth rate and greater production (Roma et al. 2012). Despite its proven effectiveness, use of $\mathrm{N}$ fertilizer by farmers is limited due to high cost. On the other hand, the legume mixture Estilozantes Campo Grande (80\% Stylosanthes capitata $+20 \%$ S. macrocephala), capable of fixing atmospheric nitrogen, has become a promising forage plant (Embrapa 2010; Ribeiro et al. 2011). However, there is still a lack of information about its use in association with grasses for animal production.

This study aims to measure the performance of livestock grazing Tanzânia grass (Panicum maximum cv. Tanzânia-1) fertilized with nitrogen or grown with Estilozantes Campo Grande (Estilozantes CG).

\section{Methods}

The work was conducted in the northwest of Paraná, Brazil (22 $50^{\prime} 16^{\prime \prime} \mathrm{S}, 51^{\circ} 58^{\prime} 22^{\prime \prime} \mathrm{W} ; 410 \mathrm{~m}$ asl) on an Oxisol soil (Embrapa 1999). The experimental design was blocks with split plots and 3 replications, the main plots being: Tanzânia + Estilozantes CG; Tanzânia +75 kg N/ha; Tanzânia +150 kg N/ha; and Tanzânia +225 $\mathrm{kg} \mathrm{N} / \mathrm{ha}$; and the subplots the seasons of the year: spring, summer and autumn. The swards were grazed continuously at variable stocking rates aiming to maintain the pasture at a height between 40 and $45 \mathrm{~cm}$ (residue). The animals used were Nellore (Zebu) with an initial average body weight of $230 \mathrm{~kg}$. Each paddock contained 3 test animals plus additional regulator animals that were added or removed depending on the height of the

Correspondence: Ulysses Cecato, Universidade Estadual de Maringá, Departamento de Zootecnia, Maringá CEP 87020-900, PR, Brazil. Email: ucecato@uem.br pasture, using the "put and take" method (Mott and Lucas 1952). Animal performance was assessed by average daily gain (ADG), estimated by the difference in weight of test animals at the beginning and end of the experiment, divided by the number of days in the pasture, with weighing every 28 days. Stocking rate (SR) was calculated from the average weight of the regulator animals, multiplied by the number of days they remained in the pasture and divided by the number of days in the period, plus the weight of the tester animals, converted to animal units/ha [450 $\mathrm{kg}$ of $\mathrm{LW}=1$ animal unit (AU)]. Analysis of variance was performed with the aid of the Statistical Analysis System and Genetic/SAEG and the averages were submitted to Tukey test at $5 \%$ probability.

\section{Results and Discussion}

The average production of dry matter (DM) of forage throughout the experimental period for Tanzânia grass intercropped with Estilozantes (CG) or fertilized with 75,150 and $225 \mathrm{~kg}$ of $\mathrm{N}$ was $3.35,3.55,3.73$ and 4.16 t/ha, respectively. In spring, summer and autumn average production was $3.89,3.66$ and $3.55 \mathrm{t} \mathrm{DM} / \mathrm{ha}$, respectively. The pasture presented $13 \%$ of Estilozantes $\mathrm{CG}$, in the total herbage mass. There was no interaction between treatments and seasons for average daily gain (ADG) or stocking rate (SR), with a significant difference between seasons (Table 1). Overall, ADGs on all treatments were similar with a mean value of 0.74 $\mathrm{kg} / \mathrm{hd} / \mathrm{d}$. On all treatments, peak weight gains per head occurred in spring with progressive declines to summer and autumn (Table 1).

Stocking rates (carrying capacity) varied with season and treatment. In general, the number of grazing animals was highest in spring and lowest in autumn but differences between summer and autumn were often small. According to Almeida (2001), an increase in SR results in a decrease in consumption of the leafy fraction of the grass, due to increased competition for the more 
Table 1. Animal performance $( \pm \mathrm{SD})$ on Tanzânia grass pasture intercropped with Estilozantes Campo Grande or fertilized with nitrogen, during the various seasons.

\begin{tabular}{|c|c|c|c|c|c|}
\hline \multirow[t]{2}{*}{ Season } & \multicolumn{4}{|c|}{ Treatments } & \multirow{2}{*}{ Mean } \\
\hline & Estilozantes CG & $75 \mathrm{~kg} \mathrm{~N}$ & $150 \mathrm{~kg} \mathrm{~N}$ & $225 \mathrm{~kg} \mathrm{~N}$ & \\
\hline \multicolumn{6}{|c|}{ Average daily gain $(\mathrm{kg} / \mathrm{hd} / \mathrm{d})$} \\
\hline Spring & $1.07 \pm 0.11$ & $0.99 \pm 0.08$ & $0.96 \pm 0.08$ & $1.03 \pm 0.03$ & $1.01 \pm 0.08 \mathrm{~A}^{1}$ \\
\hline Summer & $0.64 \pm 0.03$ & $0.62 \pm 0.08$ & $0.84 \pm 0.09$ & $0.76 \pm 0.22$ & $0.72 \pm 0.14 \mathrm{~B}$ \\
\hline Autumn & $0.46 \pm 0.12$ & $0.44 \pm 0.16$ & $0.48 \pm 0.09$ & $0.52 \pm 0.05$ & $0.48 \pm 0.10 \mathrm{C}$ \\
\hline Mean & $0.72 \pm 0.28 \mathrm{a}$ & $0.69 \pm 0.26 \mathrm{a}$ & $0.76 \pm 0.23 \mathrm{a}$ & $0.77 \pm 0.25 \mathrm{a}$ & \\
\hline \multicolumn{6}{|c|}{ Stocking rate $(\mathrm{AU} / \mathrm{ha})^{2}$} \\
\hline Spring & $2.31 \pm 0.11$ & $3.45 \pm 1.01$ & $3.75 \pm 0.81$ & $4.62 \pm 0.18$ & $3.5 \pm 1.03 \mathrm{~A}$ \\
\hline Summer & $1.78 \pm 0.12$ & $2.07 \pm 0.05$ & $2.95 \pm 0.37$ & $4.43 \pm 0.85$ & $2.8 \pm 1.15 \mathrm{~B}$ \\
\hline Autumn & $1.66 \pm 0.06$ & $2.26 \pm 0.29$ & $2.78 \pm 0.31$ & $3.16 \pm 0.07$ & $2.5 \pm 0.62 \mathrm{~B}$ \\
\hline Mean & $1.92 \pm 0.31 \mathrm{c}$ & $2.59 \pm 0.84 \mathrm{~b}$ & $3.16 \pm 0.65 \mathrm{~b}$ & $4.07 \pm 0.82 \mathrm{a}$ & \\
\hline
\end{tabular}

${ }^{\mathrm{T}}$ Means within columns and parameters, followed by the same upper-case letters and in rows followed by the same lower-case letters, do not differ by Tukey test $(\mathrm{P}<0.05)$.

${ }^{2}$ Animal units per hectare.

nutritious forage, which decreases the chance for selection of leaf. As a result, pastures fertilized with higher doses of $\mathrm{N}$ supported greater SRs due to increased forage production (Roma et al. 2012), but this did not affect ADG. The presence of Estilozantes CG, which produces forage of good nutritional value, allowed this treatment to produce similar ADGs to the $\mathrm{N}$-fertilized treatments but at a lower SR.

\section{Conclusions}

This study has shown that irrigated Tanzânia pastures can support excellent weight gains at high stocking rates in the presence of adequate levels of $\mathrm{N}$ fertilizer. Intercropping with Estilozantes Campo Grande can produce similar gains per head but at the cost of lower carrying capacity. The choice of which system to adopt will depend on relative costs of fertilizer, water and seed and the grazing time lost to establish the legume.

\section{References}

Almeida RG. 2001. Avaliação de pastagens de braquiárias consorciadas com estilosantes, sob três taxas de lotação, no cerrado. Doctoral Thesis. Universidade Federal de Viçosa, Viçosa, MG, Brazil.

Embrapa (Empresa Brasileira de Pesquisa Agropecuária). 1999. Sistema brasileiro de classificação de solos. Embrapa SPI, Brasília, DF, Brazil.

Embrapa (Empresa Brasileira de Pesquisa Agropecuária). 2010. Estilosantes Campo Grande: Leguminosa forrageira recomendada para solos arenosos do Acre. Circular técnica 55. Embrapa Acre, Rio Branco, AC, Brazil.

Mott GO; Lucas HL. 1952. The design, conduct and interpretation of grazing trials on cultivated and improved pastures. Proceedings of the VI International Grassland Congress, Pasadena, CA, USA. p. 1380-1385.

Ribeiro OL; Cecato U; Iwamoto BS; Pinheiro A; Jobim CC; Damasceno JC. 2011. Desempenho de bovinos em capimtanzânia adubado com nitrogênio ou consorciado com Estilosantes. Revista Brasileira de Saúde e Produção Animal 12:275-285.

Roma CFC; Cecato U; Soares Filho CV; Santos GT; Ribeiro OL; Iwamoto BS. 2012. Morphogenetic and tillering dynamics in Tanzania grass fertilized and non-fertilized with nitrogen according to season. Revista Brasileira de Zootecnia 41:565-573. 
Cecato U; Iwamoto BS; Peluso EP; Mari GC; Pereira VV; Saute JM. 2014. Animal performance on Tanzânia grass pasture intercropped with Estilozantes Campo Grande or fertilized with nitrogen. Tropical Grasslands - Forrajes Tropicales 2:29-30.

DOI: $\underline{10.17138 / \mathrm{TGFT}(2) 29-30}$

This paper was presented at the $22^{\text {nd }}$ International Grassland Congress, Sydney, Australia, 15-19 September 2013. Its publication in Tropical Grasslands - Forrajes Tropicales is the result of a co-publication agreement with the IGC Continuing Committee. Except for adjustments to the journal's style and format, the text is essentially the same as that published in: Michalk LD; Millar GD; Badgery WB; Broadfoot KM, eds. 2013. Revitalising Grasslands to Sustain our Communities. Proceedings of the $22^{\text {nd }}$ International Grassland Congress, Sydney, Australia, 2013. New South Wales Department of Primary Industries, Orange, NSW, Australia. p. 1538-1539. 